\title{
Avaliação do efeito dose-resposta do xilitol, associado ou não ao fluoreto, na prevenção da desmineralização erosiva e no reendurecimento do esmalte erodido: estudos in vitro
}

\section{Resumo}

A erosão dentária é definida como a perda irreversível da estrutura dentária pela ação de ácidos de origem não bacteriana. Diversos agentes, como o fluoreto $(F)$ e o xilitol, podem apresentar efeito protetor, minimizando a desmineralização erosiva da estrutura dentária. Assim, o objetivo deste estudo foi avaliar o efeito do xilitol, associado ou não ao F, no reendurecimento do esmalte erodido e na prevenção da desmineralização erosiva do esmalte in vitro. Foram realizados dois experimentos distintos. Para cada experimento, espécimes de esmalte bovino foram selecionados pela dureza de superfície (Knoop) e aleatorizados em 8 grupos ( $n=15)$, de acordo com as soluções utilizadas para tratamento do esmalte: (1) sem xilitol e sem F (controle); (2) xilitol 5\%; (3) xilitol 10\%; (4) xilitol 20\%; (5) 500 ppm F (NaF); (6) xilitol 5\% + 500 ppm F; (7) xilitol 10\% + 500 ppm F e (8) xilitol 20\% + 500 ppm F. Para a análise do efeito das soluções sobre o reendurecimento do esmalte, os espécimes foram submetidos aos desafios erosivos pela imersão em solução de ácido cítrico a $0,1 \%$, pH 2,5, por 1,5 minuto, 4 vezes, no dia 1. Entre cada desafio, os espécimes foram imersos em saliva artificial por 30 minutos, à temperatura ambiente (TA). Nos dias 2 e 3, os espécimes foram imersos nas soluções de tratamento por 1 minuto e, após, permaneceram em saliva por 30 minutos (TA). Ao final de cada dia, as análises foram realizadas por dureza de superfície. Para a análise do efeito das soluções sobre a prevenção da desmineralização, foi realizada uma ciclagem de pH erosiva por 5 dias. Em cada dia de ciclagem, os espécimes foram tratados com as soluções por 1 minuto, submetidos aos desafios erosivos (4x/dia) e tratados com as soluções novamente. Entre cada desafio, os espécimes foram imersos em saliva por 30 minutos. Ao final do $1^{\circ}$ e do $5^{\circ}$ dia de ciclagem, as análises foram realizadas por dureza de superfície e por perfilometria de contato, respectivamente. As soluções contendo xilitol 10\%, xilitol 10\% + 500 ppm F e xilitol $20 \%+$ $500 \mathrm{ppm} F$ foram as mais eficazes em promover o reendurecimento do esmalte, diferindo dos demais grupos no $2^{\circ}$ dia de tratamento $(\mathrm{p}<0,05)$. Todas as soluções reduziram significativamente o amolecimento e o desgaste erosivo do esmalte em relação ao grupo controle $(p<0,05)$, sem diferenças significativas entre si, com exceção das soluções contendo xilitol 10\% + 500 ppm F e 500 ppm F que, dentre as soluções testadas, apresentaram o menor e o maior valor de desgaste erosivo, respectivamente. Os resultados mostraram que a solução de xilitol a 10\% apresentou melhor potencial para reendurecer o esmalte, independente da presença do F, e melhor efeito anti-erosivo, quando associado ao F. Os resultados sugerem que o xilitol promove o reendurecimento de lesões erosivas e previne a desmineralização erosiva do esmalte in vitro, independente da presença do $\mathrm{F}$. 